\title{
RAS Mutations in Preleukaemias
}

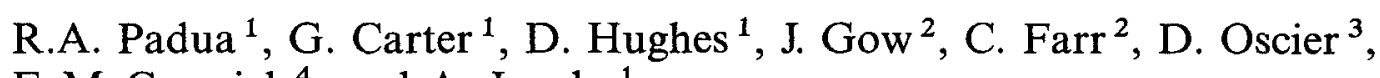
F. McCormick ${ }^{4}$, and A. Jacobs ${ }^{1}$

Activated ras genes have been implicated in a wide variety of neoplasms [2]. N-ras in particular has been shown to be involved in acute myelogenous leukaemia (AML) with activating mutations around codons $12 / 13$ and $61[3,7]$. The myelodysplastic syndromes (MDS) are a group of preleukaemias, a proportion of which will develop AML. Hirai et al. [9] described three MDS patients with N-ras mutations in codon 13 and Liu et al. [12] showed K-ras activations in two MDS patients. In this study we have screened DNA from peripheral blood or bone marrow of 50 MDS patients for ras mutations around codons 12/13 and 61 of $\mathrm{H}, \mathrm{K}$ and $\mathrm{N}$-ras and around codon 117 of $\mathrm{N}$-ras. A mutation in position 117 of $\mathrm{H}$ ras has been reported to be an activating mutation in vivo in chemically induced murine liver tumours [15]. Mutations in codons 116-119 of H-ras have been shown to reduce the ability of the H-ras p21 protein to bind and hydrolyse guanosine triphosphate (GTP) and some of these mutations are capable of activating the transforming potential of the normal gene $[5,20]$.

Using an amplification procedure called polymerase chain reaction (PCR) [16] and hybridisation with synthetic oligonucleotide probes [7, 21], ras mutations were detected in 20/50 (40\%) MDS

1 Leukaemia Research Fund Preleukaemia Unit, University of Wales College of Medicine, Heath Park, Cardiff, UK

${ }^{2}$ Institute of Cancer Research, London, UK

3 Royal Victoria Hospital, Bournemouth, UK

${ }^{4}$ Cetus Corporation, Emeryville, California, USA patients (Table 1). Fourteen N-ras mutations were observed (ten in codons 12/13 and four in codon 61), six K-ras mutations in codon 12 and two H-ras mutations (one in codon 12 and one in codon 61). Two patients had mutations in two different ras genes. This gives a total of 22 mutations from 50 individuals. Details of the patients and substitutions observed in these mutants have been reported elsewhere [14]. To date no mutations were observed with mutant-specific oligonucleotide probes to position 117.

Independent confirmation of these results were obtained with DNA from 11 patients with detectable ras mutations by using transformation assays (Table 2). A tumorigenicity assay identified another sideroblastic anaemia (RARS) patient with an N-ras-activated gene $(G D)$. As this was not detected by the oligonucleotide screen, it is possible that the number of mutant ras-containing cells is very low. Another chronic myelomonocytic leukaemia (CMML) patient (RP86CMML) with an N13 Ala substitution progressed approximately 1 year later to AML (RP87-AML). The mutation in the AML (RP87) stage was no longer detectable by PCR (Fig. 1 A). An N-ras clone pAT 8.8 with normal sequences around codon 12 [8] was used as a control. Other controls include HM-CMML, another N13 Ala-containing mutant and BMPASA (sideroblastic anaemia or RARS). This observation was confirmed by directly hybridising the N13 Ala probe to unamplified DNA and showing differential hybridisation (Fig. 1 B). Using a minisatellite probe 33.6 [10], the DNA fingerprints confirmed that both samples were derived from the same patient (Fig. 1C). 


\begin{tabular}{|c|c|c|}
\hline & $\begin{array}{l}\text { No. ras mutants/ } \\
\text { No. samples }\end{array}$ & Substitution \\
\hline Controls & $0 / 10$ & \\
\hline $\begin{array}{l}\text { Myelodysp } \\
\text { RAS }\end{array}$ & $2 / 13$ & $\begin{array}{l}1 \times \mathrm{H} 61 \operatorname{Arg}(A \rightarrow G) \\
1 \times N 12 \operatorname{Val}(G \rightarrow T) \\
1 \times \mathrm{K} 12 \operatorname{Asp}(G \rightarrow A)\end{array}$ \\
\hline RA & $4 / 13$ & $\begin{array}{l}1 \times \mathrm{N} 12 \operatorname{Asp}(\mathrm{G} \rightarrow \mathrm{A}) \\
1 \times \mathrm{N} 12 \operatorname{Val}(\mathrm{G} \rightarrow \mathrm{T}) \\
1 \times \mathrm{N} 61 \operatorname{Leu}(\mathrm{A} \rightarrow \mathrm{T}) \\
1 \times \mathrm{K} 12 \operatorname{Asp}(\mathrm{G} \rightarrow \mathrm{A})\end{array}$ \\
\hline RAEB & $3 / 8$ & $\begin{array}{l}1 \times \mathrm{N} 12 \operatorname{Ala}(\mathrm{C} \rightarrow \mathrm{G}) \\
1 \times \mathrm{N} 12 \operatorname{Asp}(\mathrm{G} \rightarrow \mathrm{A}) \\
1 \times \mathrm{K} 12 \operatorname{Arg}(\mathrm{G} \rightarrow \mathrm{C})\end{array}$ \\
\hline CMML & $11 / 16$ & $\begin{array}{l}1 \times \mathrm{N} 12 \mathrm{Ala}(\mathrm{G} \rightarrow \mathrm{C}) \\
1 \times \mathrm{N} 12 \mathrm{Asp}(\mathrm{G} \rightarrow \mathrm{A}) \\
3 \times \mathrm{N} 13 \mathrm{Ala}(\mathrm{G} \rightarrow \mathrm{C}) \\
3 \times \mathrm{K} 12 \mathrm{Asp}(\mathrm{G} \rightarrow \mathrm{A}) \\
1 \times \mathrm{H} 12 \mathrm{Val}(\mathrm{G} \rightarrow \mathrm{T}) \\
3 \times \mathrm{N} 61 \mathrm{His}(\mathrm{A} \rightarrow \mathrm{C})\end{array}$ \\
\hline Total & $20 / 50(40 \%)$ & \\
\hline
\end{tabular}

Square brackets indicate mutations of the two patients with double mutations. RARS, refractory anaemia with ringed sideroblasts; RA, refractory anaemia; RAEB, refractory anaemia with excess blasts; CMML, chronic myelomonocytic leukaemia.

Both RP86-CMML and RP87-AML registered in a transformation assay (Table 2).

Several investigators have suggested that there is a heterogeneity of leukaemic cells with respect to the presence of an activated ras gene and that in some patients only a fraction of the malignant cells carry the mutant gene $[18,17,7]$. Similarly, heterogeneity in malignant melanoma has been described [1] where $\mathrm{N}$-ras activation was detected in one out of five cultured tumour cell lines established from metastases of a melanoma patient. One explanation of these results is that mutations occur late, after a preleukaemic clone has already emerged, and give the premalignant clone an additional growth advantage. An alternative explanation is that the ras mutation occurs early in the preleukaemic process and there is later evolution with the emergence of a clone in which another gene has been activated. Our observations of activated ras genes in 21 preleukaemic patients argue for the latter explanation, though there is no evidence that this is an initiating event in leukaemogenesis. The possible reduction of a mutant ras gene with leukaemic transformation in one case also supports this argument. Similar observations have also been described in AMLs [7]. The evidence for such clonal evolution in leukaemogenesis is compelling $[11,6]$ and, in many cases, this may be clearly seen in serial karyotype studies [13, 19].

The incidence of ras mutations in the different FAB groups do not differ from those expected, with the exception of the CMMLs with a higher than expected frequency $(P=0.02)$ (Table 3). To date, 8 of the 21 patients with mutant ras genes transformed to AML compared with 4 of the 29 patients with no detectable ras mutations. Out of the latter four, one of 
Tumorigenicity assay

Table 2. Transformation assays

\begin{tabular}{lll}
\hline $\begin{array}{l}\text { No. tumours } \\
\text { No. sites }\end{array}$ & $\begin{array}{l}\text { Latency } \\
\text { injected }\end{array}$ & $\begin{array}{l}\text { Transforming } \\
\text { gene and }\end{array}$ \\
& & substitution
\end{tabular}

\begin{tabular}{|c|c|c|c|c|}
\hline \multicolumn{5}{|l|}{ Controls } \\
\hline \multirow{2}{*}{\multicolumn{2}{|c|}{$\begin{array}{l}\text { NIH3T3 } \\
\text { EJ focus }\end{array}$}} & $2 / 30$ & 33 & - \\
\hline & & $16 / 16$ & 21 & $\mathrm{Ha} 12 \mathrm{val}$ \\
\hline \multicolumn{5}{|c|}{ Myelodysplasia } \\
\hline \multirow[t]{4}{*}{ RARS } & $\mathrm{CN}$ & $8 / 8$ & 38 & $\mathrm{~N} 12 \mathrm{val}+\mathrm{H}-\mathrm{ras}$ \\
\hline & GD & $6 / 8$ & 19 & N-ras \\
\hline & PW & $0 / 8$ & - & - \\
\hline & ZG & $0 / 8$ & - & - \\
\hline \multirow[t]{2}{*}{ RA } & OB & $8 / 8$ & 21 & N-ras \\
\hline & GB & $6 / 6$ & 10 & N61 leu \\
\hline \multirow[t]{3}{*}{ RAEB } & KS & $5 / 8$ & 22 & N12 ala \\
\hline & TB & $3 / 8$ & 22 & $\mathrm{~N} 12$ ala \\
\hline & JO & $0 / 8$ & - & - \\
\hline \multirow{7}{*}{ CMML } & HM & $3 / 8$ & 36 & N13 ala \\
\hline & RP 1986 & $3 / 8$ & 24 & N13 ala \\
\hline & DP & $5 / 8$ & 27 & N-ras \\
\hline & $\mathrm{HE}$ & $4 / 8$ & 26 & K-ras \\
\hline & HW & $4 / 8$ & 23 & Non-ras \\
\hline & $\mathrm{JN}$ & $0 / 8$ & - & - \\
\hline & AT & $0 / 8$ & - & - \\
\hline
\end{tabular}

Acute myelogenous leukaemia

\begin{tabular}{|c|c|c|c|c|}
\hline & RP 1987 & $6 / 8$ & 24 & N-ras \\
\hline & & \multicolumn{3}{|c|}{ Focus formation } \\
\hline & & \multicolumn{3}{|c|}{$\begin{array}{l}\text { Transformation frequency } \\
\text { Foci/ } \mu \text { g DNA } \\
\text { (No. foci/No. flasks) }\end{array}$} \\
\hline \multicolumn{5}{|l|}{ Controls } \\
\hline $\begin{array}{l}\text { NIH3T3 } \\
\text { EJ focus }\end{array}$ & & $\begin{array}{lr}0 & (0 / 5) \\
0.2 & (20.5)\end{array}$ & $\mathrm{Ha} 12 \mathrm{val}$ & \\
\hline \multicolumn{5}{|c|}{ Myelodysplasia } \\
\hline $\begin{array}{l}\text { CMML } \\
\text { CMML } \\
\text { RA }\end{array}$ & $\begin{array}{l}\text { FB } \\
\text { MB } \\
\text { HW }\end{array}$ & $\begin{array}{ll}0.06 & (6 / 5) \\
0.04 & (8 / 10) \\
0.017 & (5 / 15)\end{array}$ & $\begin{array}{l}\text { N12 asp } \\
\text { H12 val } \\
\text { Non-ras }\end{array}$ & \\
\hline
\end{tabular}

Twenty micrograms of DNA was transfected onto NIH3T3 cells which were plated at a density of $3 \times 10^{5} 24 \mathrm{~h}$ earlier. Precipitates were left overnight and media changed the next day. For tumorigenicity assays 1-2 $\mu$ g PHSG272, a neomycin-resistance-containing cosmid [4], was cotransfected with genomic DNAs. Three days after transfection, cells were split into G418-containing media $(800 \mu \mathrm{g} / \mathrm{ml})$, resistant colonies were selected and $10^{6}$ cells/site were injected in both of the hind flanks of athymic nude mice. Tumours with latency periods of less than 6 weeks were scored and analysed. For focus formation assays media were changed every 3 days in $5 \%$ serum. Foci were scored 3 weeks after transfection. One hundred micrograms of DNA of each sample was used per experiment and three to four mice were injected. 


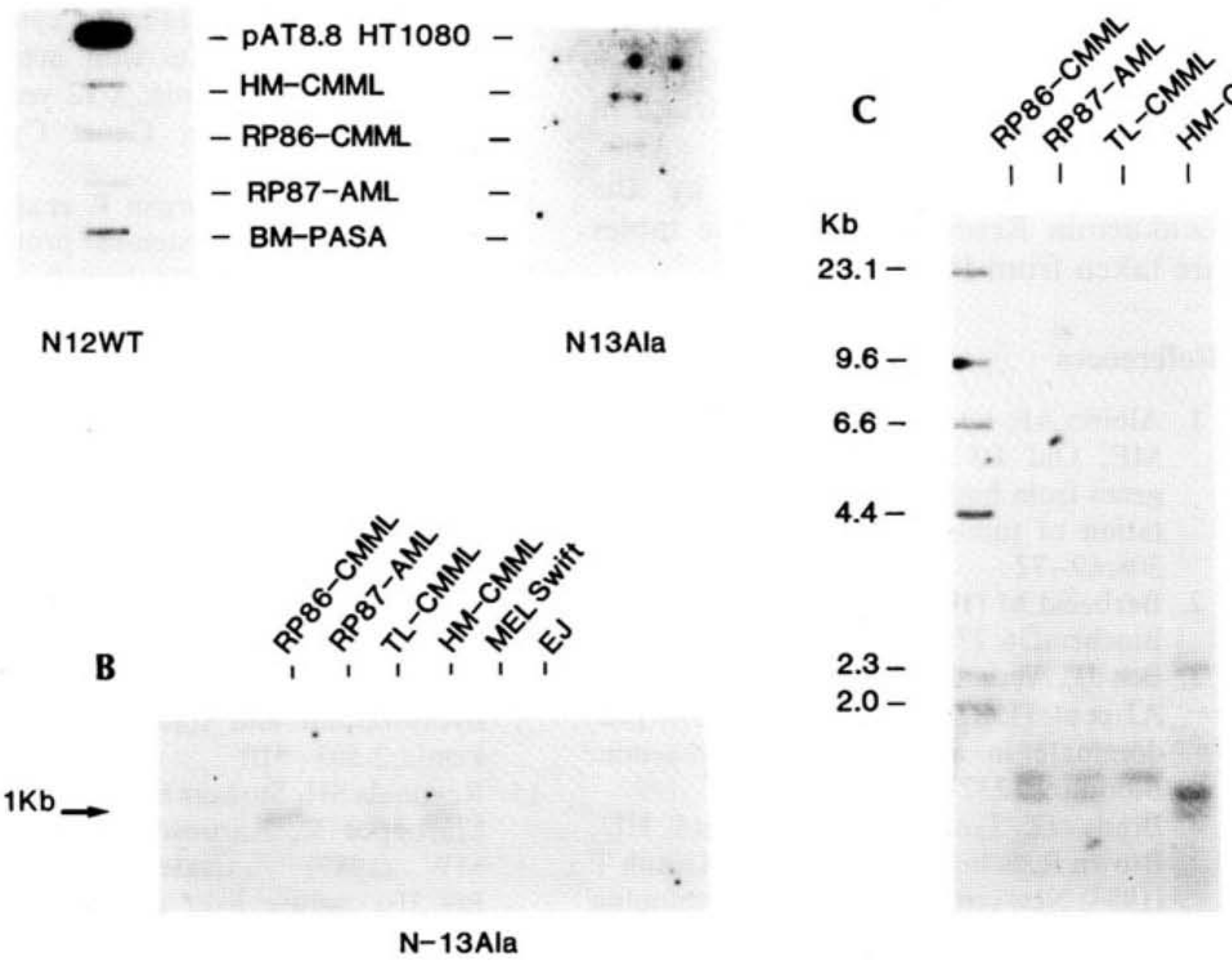

Fig. 1 A-C. Presence of N13 mutations in CMML and absence of mutation in AML. Amplified DNA was slot blotted and hybridised with N12/13 wild-type or N13 ala probes (A). Ten nanograms of cloned N-ras pAT $8.8 \mathrm{HT} 1080$ [8] was used as a control. PvuII-digested DNA was electrophoresed and dried gels were hybridised to the N13 ala probe (B). HinfI-digested DNA was electrophoresed, transferred and filters hybridised to the minisatellite probe 33.6 [10] (C)

Table 3. Frequency of normal and mutant genes in RARS, RA, RAEB and CMML

\begin{tabular}{llllll}
\hline & RARS & RA & RAEB & CMML & Total \\
\hline Normal & $10(7.5)$ & $9(7.5)$ & $5(4.6)$ & $5(9.3)$ & 29 \\
Abnormal & $\frac{3}{13}(5.5)$ & $\frac{4}{13}$ & $\frac{3}{8}$ & $\frac{11}{16}$ & $\frac{21}{50}$ \\
\hline
\end{tabular}

Figures in brackets are the frequencies that would be expected if the prevalence of mutant genes was the same in each group, and equal to the overall rate of $21 / 50=42 \%$. A comparison of these expected frequencies with those actually observed by the exact test indicates that there are more CMML patients with mutant genes than would be expected $\left(\chi^{2}=5.39, P=0.02\right)$.

these patients (H.W.) had a detectable transforming gene which is not an activated ras gene (Table 2, RA-HW and CMML-HW). Transformants for both the refractory anaemia (RA) and CMML stages were anchorage independent and tumorigeneic in nude mice. DNA from the three non-mutated patients which progressed to AML have been found to be negative when tested in transformation assays (RAEB-JO; CMML-JN and CMML-AT). In agreement with Hirai et al. [9] and Liu et al. [12], our results show that MDS patients with mutations may evolve to AML more frequently than those without mutations. Thus, the 
presence of such mutations may be of prognostic value. However, clearly there are other factors which are important in progression.

This work was supported by the Leukaemia Research Fund. The tables are taken from Padua et al. [14].

\section{References}

1. Albino AP, Le Strange R, Oliff AI, Furth ME, Old LJ (1984) Transforming ras genes from human melanoma: a manifestation of tumour heterogeneity? Nature 308:69-72

2. Barbacid M (1987) Ras genes. Annu Rev Biochem 56:779-827

3. Bos JL, Verlaan-de Vries $\mathrm{M}$, Van der Eb AJ et al. (1987) Mutations in N-ras predominate in acute myeloid leukaemia. Blood 69:1237-1241

4. Brady G, Jantzen HM, Bernard HU, Brown R, Schutz G, Hashimoto-Gotoh T (1984) New cosmid vectors for developing eukaryotic DNA cloning. Gene 27:223232

5. Clanton DJ, Hattori S, Shih TY (1986) Mutations of the ras gene product p21 that abolish nucleotide binding. Proc Natl Acad Sci USA 83:5076-5080

6. Fearon ER, Philip BA, Burke PJ, Schiffer CA, Zohnbauer BA, Vogelstein B (1986) Differentiation of leukemia cells to polymorphonuclear leukocytes in patients with acute nonlymphocytic leukemia. $\mathrm{N}$ Engl J Med 315:15-24

7. Farr CJ, Saiki RK, Erlich HA, McCormick F, Marshall CJ (1988) Analysis of ras gene mutations in acute myeloid leukaemia by polymerase chain reaction and oligonucleotide probes. Proc Natl Acad Sci USA 85:1629-1633

8. Hall A, Marshall CJ, Spurr NK, Weiss RA (1983) Identification of transforming genes in two human sarcoma cell lines as a new member of the ras gene family located on chromosome 1. Nature 303:396400

9. Hirai $\mathrm{H}$, Kobayshi $\mathrm{Y}$, Mano $\mathrm{H}$ et al. (1987) A point mutation at codon 13 of the N-ras oncogene in myelodysplastic syndrome. Nature 327:430-432

10. Jeffreys AJ, Wilson V, Thein SL (1985) Hypervariable 'minisatellite' regions in human DNA. Nature 314:67-73

11. Larson RA, Le Beau M, Vardiman JW, Testa JR, Golomb HM, Rowley JV (1983)
The predictive value of initial cytogenetic studies in 148 adults with acute nonlymphoblastic leukemia: a 12 year study (1970-1982). Cancer Genet Cytogenet 10:219-236

12. Liu E, Hjelle B, Morgan R et al. (1987) Mutations of the Kirsten-ras proto-oncogene in human preleukaemia. Nature 300:186-188

13. Mecucci C, Rege-Cambrin G, Michaux J-L, Tricot G, Van den Berghe H (1986) Multiple chromosomally distinct cell populations in myelodysplastic syndromes and their possible significance in the evolution of the disease. $\mathrm{Br} \mathrm{J}$ Haematol 64:699-706

14. Padua RA, Carter G, Hughes D et al. (1988) Ras mutations in myelodysplasia detected by amplification, oligonucleotide hybridisation and transformation. Leukemia 2:503-510

15. Reynolds SH, Stowers ST, Patterson RM, Maronpot R, Aaronson SA, Anderson MW (1987) Activated oncogenes in B6C3F1 mouse liver tumours: implications for risk assessment. Science 237: 1309-1316

16. Saiki RK, Bugawan TC, Horn GT, Mullis KB, Erlich HA (1986) Analysis of enzymatically amplified beta-globin and HLA-DQalpha DNA with allele-specific oligonucleotide probes. Nature 324:163166

17. Shen WP, Aldrich TH, Venta-Perez G, Granza BR Jr, Furth ME (1987) Expression of normal and mutant ras proteins in human acute leukemia. Oncogene 1:157165

18. Toksoz D, Farr CJ, Marshall CJ (1987) Ras gene activation in a minor population of the blast population in acute myeloid leukaemia. Oncogene 1:409-413

19. Tomonaga M, Tomonaga $Y$, Kusano $M$, Ichimaru U (1984) Sequential karyotypic evolutions and bone marrow aplasia preceding acute myelomonocytic transformation from myelodysplastic syndrome. $\mathrm{Br} \mathbf{J}$ Haematol 58:53-60

20. Walter M, Clark SG, Levinson AD (1986) The oncogenic activation of human pn21 ras by a novel mechanism. Science 233:649-652

21. Wood WI, Gitschier J, Lasky LA, Lawn RM (1985) Base composition-independent hybridization in tetramethylamonium chloride: a method for oligonucleotide screening of highly complex gene libraries. Proc Natl Acad Sci USA 82:1585-1588 